\title{
Working Memory and Reading Development
}

\author{
T. L. Ferreira ${ }^{1 *}$, C. M. T. Valentin ${ }^{2}$, S. M. Ciasca ${ }^{1}$ \\ ${ }^{1}$ Department of Neurology, Research Laboratory of Learning and Attention Disorders \\ (DISAPRE), São Paulo, Brazil \\ ${ }^{2}$ Applied Neuropsychology of Child Neurology School of Medical Sciences, State University of Campinas \\ (UNICAMP) Campinas, São Paulo, Brazil \\ Email: ${ }^{*}$ ferr.tais@gmail.com
}

Received July 24 ${ }^{\text {th }}$, 2013; revised August 25 ${ }^{\text {th }}$, 2013; accepted September $28^{\text {th }}, 2013$

\begin{abstract}
Copyright (C 2013 Tais de Lima Ferreira et al. This is an open access article distributed under the Creative Commons Attribution License, which permits unrestricted use, distribution, and reproduction in any medium, provided the original work is properly cited.
\end{abstract}

\begin{abstract}
Purpose: To evaluate the development of working memory and reading in proficient students from 1st to 4th year of elementary school. Method: Participants were 19 people of both genders, with an average age of 8.26 years, enrolled between the 1st and 4th year of elementary school, who met the proposed inclusion criteria and were proposed and evaluated for working memory and reading level. Results: There're no significant differences in the level of reading and working memory between genders male and female. The research points to an improved performance of working memory with the increasing age and educational level. The students belonging to the 3rd and 4th year showed better results in the physical assessment of working memory, as well as in the evaluation of the reading level. Conclusion: In this study, it was observed that with the increasing age and schooling, there was an improvement in the performance of working memory, and consequently a better performance in reading. But it cannot be inferred that only the working memory and reading complement themselves bidirectionally, because the literature indicates that other factors also help the development of reading.
\end{abstract}

Keywords: Short Term Memory; Performance Evaluation; Reading

\section{Introduction}

The basic operations of memory are encoding, storage and retrieval. Encoding is the transformation of sensory input in the form of mental representation that can be stored. The storage is the storage of coded information. Retrieval refers to the access and use of the information stored. These processes interact with each other and are interdependent (Sternenberg, 2000).

There are four components of working memory: central executive, phonological loop, visual-spatial layout and episode buffer (Baddeley, 2000).

According to the study above, the central executive is used to perform tasks that require greater cognitive ability, being responsible for certain functions such as selective attention, mental flexibility, select and execute plans and strategies; ability to allocate resources elsewhere in the working memory, and ability to recall information stored in the long-term memory (Baddeley, 2000).

The phonological loop is responsible for the storage and processing of information encoded verbally. The "phonological loop" is responsible for its storage of verbal material and is comprised of two components: a phonological storer and an articulatory rehearsal component (sub-vocal feedback). The storer is a component of the short term phonological retention of auditory information that is subject to rapid deterioration. Yet, the sub-vocal articulatory rehearsal feeds back the information, preventing it from deterioration and, keeping it in memory until it can be consolidated into other mnemonic levels (Ferreira, 2011).

*Corresponding author.
The phonological working memory (WM) integrates frontal mechanisms to the language for organizing sequences of responses; one must compare all the possibilities to reach its goal, which requires WM, i.e., storage and processing of information needed to perform cognitive tasks, such as language comprehension, learning and reasoning (Carrilo-Mora, 2010).

The visual-spatial scheme (sketchpad), responsible for the processing and storage of visual and/or spatial and verbal material encoded in image form, is used in remembrance of shapes, colors, location or objects speed in space, and in tasks involving spatial and motion planning. It can be considered as a link between the visual and spatial information, which can be accessed by the sense organ or long-term memory (Ferreira, 2011).

The fourth component is the episodic buffer, a temporary storage system with limited capacity, which is capable of integrating information from various sources. It is assumed that it is controlled by the executive core, and that it is capable to retrieve information that are stored, and when necessarily handle or modify them (Mourão Jr. \& Melo, 2011).

Cognitive processes involved in reading and writing are related to the phonological processing, including memory and phonological awareness. The relationship between memory, phonological awareness and written language is very expressive. The relationship between memory, phonological awareness and written language is very expressive, most particularly, the relationship between the working memory and reading, observing that the former is linked to the complex cognitive functions, where one of them, is the understanding of the language. Thus it is necessary that their operation is complete, so that this individual presents development of reading ability and comprehen- 
sion of the reading material. In addition, there are differences between the storage capacities of the memory in the different ages (Mourão Jr. \& Melo, 2011).

Children with reading difficulties also show difficulties in reverb tasks and storage of phonological information. They present a worse performance than that observed good readers (Kibby, Marks, Morgan, \& Long, 2004). This difference is even greater when the complexity of the task is increased, requiring even more phonological reverberation, or sub-vocal feedback of the reading material.

The phonological deficit hypothesis is frequently used to explain the problems related to reading and writing. Students with reading disabilities, and problems with reading comprehension as a result of changes in the phonological processing which also involves the low storage capacity of information in the working memory (Tenório \& Ávila, 2012; Van der Leij \& Morfidi, 2006; Capellini \& Conrado, 2009)

In order to better understand the development of reading and its relation to the working memory, the aim of this study was to evaluate the development of the working memory and reading in proficient students from the 1st to 4th year of elementary school.

\section{Method}

\section{Participants}

The study enrolled 19 subjects from 1st to 4th year of elementary public school that serves students from Nursery to middle school. The study was conducted after approval by the Ethics in Research (View 805/2011) of the institution. This group consisted of 12 male subjects and 13 females, aged between six and ten years old, with an average age of 8.26 years $(0.88+)$.

The inclusion criteria for participation in this study were: a normal psychomotor development, normal development of speech, hearing and visual acuity proven through tests that are performed in the children at this school from the 1st grade level. The results of the tests measuring visual and auditory acuity are delivered to school by the parents, following suggestions from the teaching staff, and the data are filed in the student file. The inclusion criteria are: no complaint of learning problems in reading, writing and arithmetic, and performance above average in reading, writing and arithmetic in TEA (Test of Educational Achievement). The exclusion criteria were: complaints of speech-language disorders, such as learning disabilities, delayed speech, phonetic and/or phonological having failed in some elementary grade; doing tutoring and/or attend educational psychology service, make use of neurological and psychiatric medication; being or have attended speech therapy; complain of cognitive performance below normal standards, and lower performance in reading, writing and arithmetic in TEA.

To help fulfill the inclusion and exclusion criteria questionnaire was used, which was filled by the parents for the selection of subjects who would participate in. In the above, there were the following questions: Did he attend kindergarten for at least two years? Does he present the framework of neurological disease? Does he present sensory deficit? Does he display motor change? Did he show developmental delay? Does the child make use of neuropsychiatric medication?

\section{Materials}

To assess the working memory, was used the Work Memory
Protocol Assessment (Ferreira, 2011) which is composed of auditory and visual evidence, tasks of free recall and serial on the forward and reverse, repetition of words and non-words and tasks Forward and Backward for visual and audio material. The tests are linguistically balanced according to the complexity of speech articulation, word length and degree of familiarity of the words in Portuguese. The protocol is divided into six stages: 1) repetition in direct order, 2) free recall, 3) verbal span, 4) visual span, 5) do not repeat words, 6) memory in reverse order. In step 1 , the serial repetition is two and three syllable words with different semantics and equal phonology; phonology words with different/same semantics, words with different phonology and semantics. In step 2, the lists of free repeating included polysyllabic words with phonology complex and different se- mantics, phonology words with different and the same semantic field (color); syllable words with equal phonology and different semantics, words with different semantics and phonology; polysyllabic words with different semantics and phonology. Step 3, (verbal span) consists of a list of two-syllable words with equal phonology and two-syllable words with different semantics. Step 4, (visual span) consists of colored cards, which must be remembered in the forward and reverse order, according to the stimulus given by the applicator. Step 5, works with the repetition of non-syllable words and three syllables. Step 6, involves and recall in reverse order a list of two-syllable words.

The reading assessment was performed by the Reading Level Protocol Assessment. The subjects read the text "Bunny Somersault" (Nauhum, 1990). The protocol allowed the reading level of the same rank in 3 levels: logographic, alphabetic spelling. According to Frith (1985), the logographic stage occurs in the recognition of familiar words, and itis evident in the graphic characteristic, not taking into consideration the order of the letters in the word. The words are read as a whole. In the alpha stage the child begins to use the correspondences between phonemes and graphemes, thus acquiring knowledge about the alphabetic principle by means of phonological awareness. First, the simples rules are learned (sequential decoding), and then, the contextual rules (hierarchical decoding). At this stage, there is still no complete understanding of the reading material. In the last stage, the spell, the subject is able to analyze words into orthographic units (groups of letters and morphemes) without performing the phonological conversion. These orthographic units, such as syllables, form a unit whose combination may generate an almost unlimited number of words.

\section{Procedures}

The subjects underwent the following tests: Test of Educational Achievement (TDE) (Stein, 1994), Working Memory Assessment Protocol (Ferreira, 2011) and Reading Level Assessment Protocol (Capellini \& Cavalheiro, 2001). Individual sessions were conducted lasting approximately 20 minutes.

\section{Data Analysis}

For this study were performed some analyses by descriptive and inferential statistics using SPSS for Windows (version 20.0). Descriptive analyses were performed to characterize the groups and inferential analyses to compare the performance between the groups (Mann Whitney, Correlation coefficient of Spearman), considered the significance level of $5 \%$, i.e., $p<$ 
0.05 .

The Mann-Whitney aims to investigate possible differences in the working memory performance between groups.

\section{Results}

Observe that all 1st year students have alphabethic reading level. Figure 1 does not show the level logographic because no participant achieved this rating. In the 2nd year they obtained levels of alphabetic spelling, remaining $20 \%$ at the orthographic level and $80 \%$ at the alphabetic. All subjects of 3rd and 4th year reached the orthographic level.

As seen in Table 1, with increasing level of education, or grade, a higher reading level between subjects. From the 3rd year all subjects were on stage spelling reading.

Figure 2 indicates the comparison of the level of reading spelling between genders male and female. It was observed that $75 \%$ of the male subjects presented and $25 \%$ of the female in the 2nd year presented reading classified in the orthographic level. In the 3rd year the subjects of both sexes presented reading in the orthographic level. In the 4th year, all male subjects were at the orthographic level.

In order to understand better the following tables, the names used for each subtest were transformed into abbreviations as shown above (Figure 3).

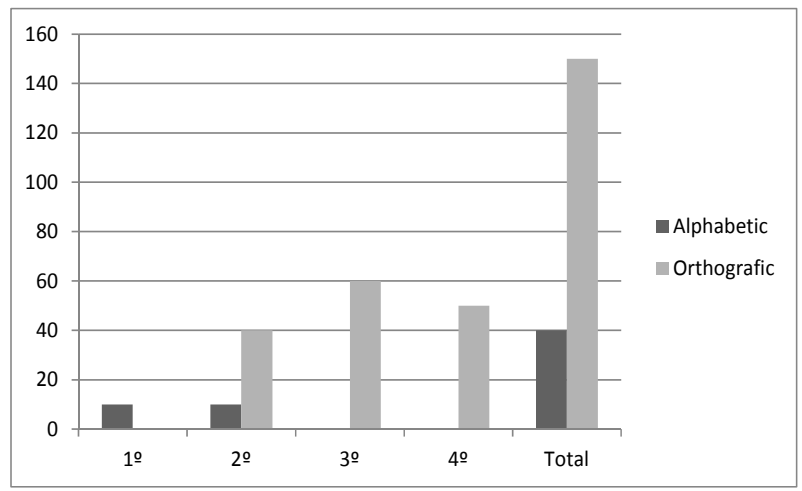

Figure 1.

Comparison of the reading level and the series.

Table 1.

Relationship between grade and reading level.

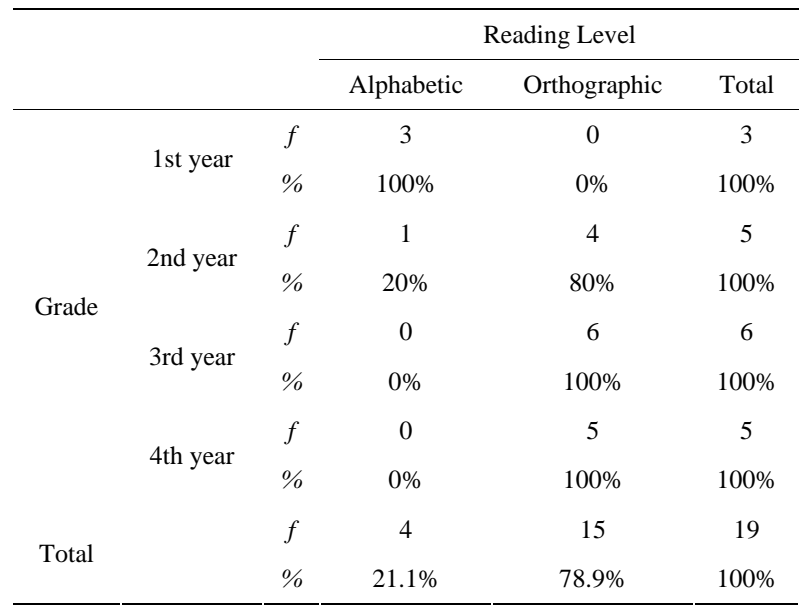

Note: $\mathrm{f}=$ frequency.

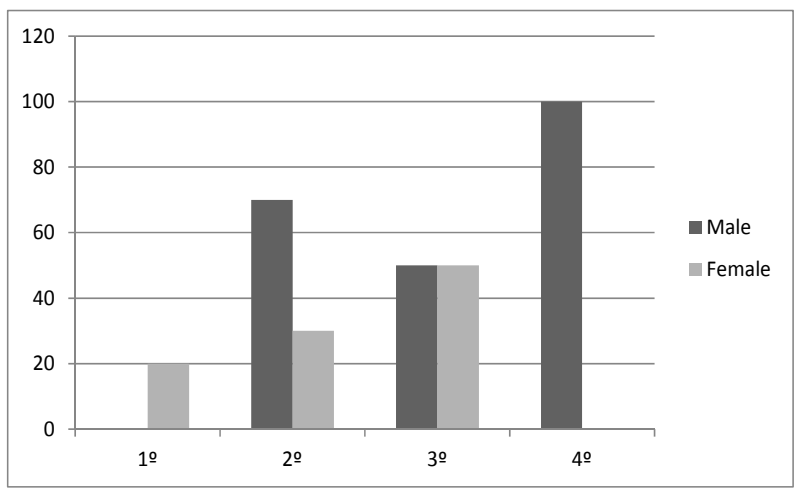

Figure 2.

Comparison of the reading level spelling between males and females.

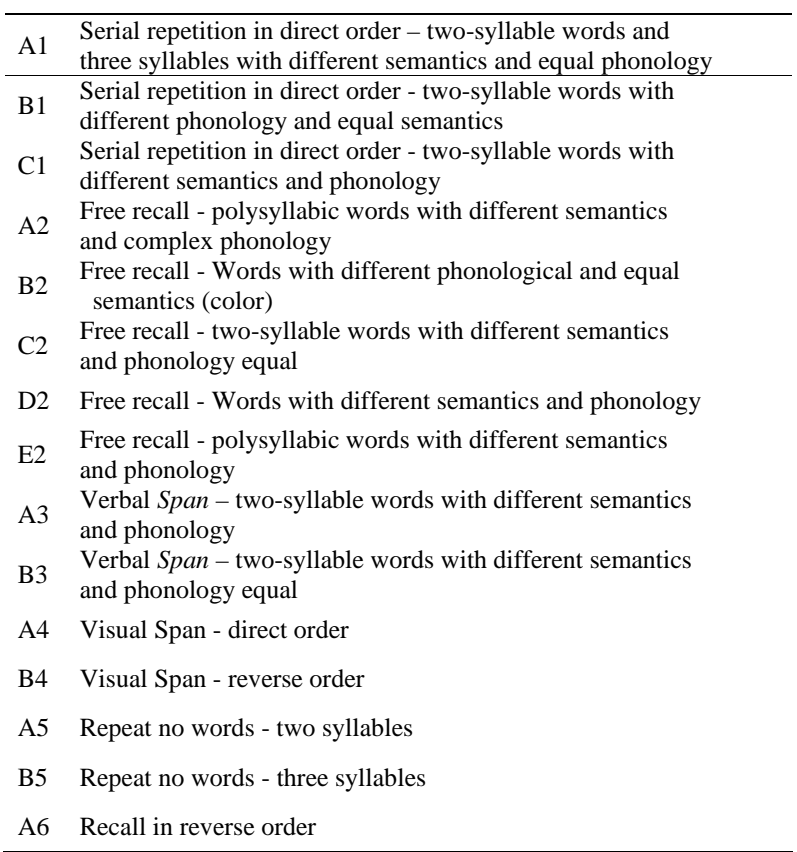

Figure 3.

Acronyms subtests of the working memory assessment protocol.

In the above table, (Table 2) the groups were divided by reading level (Alphabetical and Spelling) and the average performance on each subtest memory were compared. The results that showed differences statistically significant $(p<0.005)$ are indicated with a $\operatorname{star}(*)$. The table shows that subjects with reading at the orthographic level presented a better average performance on the subtests of the assessment protocol of working memory and that this group showed a statistically significant difference in performance when compared to the performance of the group with reading in alphabetic level B1 on the subtests, C1, A2, C2, B3, B5 and B6. The subtests of visual nature A4 and B4 showed no results with statistically significant differences in relation to levels of reading and spelling alphabet.

Table 3 indicates the presence of a positive correlation between increasing age and the increase of performance in the tests working memory B1, C1, A2, C2, A4, B5 and A6. In other words, the older the subject is, the higher the subtests scores are. 
Table 2.

Comparison of reading levels with the subtests of the assessment protocol of working memory.

\begin{tabular}{|c|c|c|c|c|c|}
\hline Test & Reading Level & $N$ & $A$ & $S D$ & $p$ value \\
\hline \multirow{2}{*}{ A1 } & Alphabetic & 4 & 6.00 & 2.48 & \multirow{3}{*}{0.39} \\
\hline & Orthographic & 15 & 7.16 & 1.41 & \\
\hline \multirow{2}{*}{ B1 } & Alphabetic & 4 & 4.50 & 0.82 & \\
\hline & Orthographic & 15 & 5.57 & 0.46 & \multirow[t]{2}{*}{$0.02^{*}$} \\
\hline \multirow{2}{*}{$\mathrm{C} 1$} & Alphabetic & 4 & 3.13 & 2.06 & \\
\hline & Orthographic & 15 & 5.60 & 1.06 & \multirow[t]{2}{*}{$0.02^{*}$} \\
\hline \multirow{2}{*}{ A2 } & Alphabetic & 4 & 2.25 & 0.50 & \\
\hline & Orthographic & 15 & 4.40 & 1.50 & \multirow[t]{2}{*}{$0.01^{*}$} \\
\hline \multirow{2}{*}{ B2 } & Alphabetic & 4 & 4.50 & 2.38 & \\
\hline & Orthographic & 15 & 5.53 & 1.96 & \multirow[t]{2}{*}{0.57} \\
\hline \multirow{2}{*}{$\mathrm{C} 2$} & Alphabetic & 4 & 2.25 & 0.96 & \\
\hline & Orthographic & 15 & 4.13 & 1.19 & \multirow[t]{2}{*}{$0.02^{*}$} \\
\hline \multirow{2}{*}{ D2 } & Alphabetic & 4 & 2.50 & 1.00 & \\
\hline & Orthographic & 15 & 3.93 & 1.67 & \multirow[t]{2}{*}{0.09} \\
\hline \multirow{2}{*}{ E2 } & Alphabetic & 4 & 2.75 & 1.50 & \\
\hline & Orthographic & 15 & 3.20 & 1.32 & \multirow[t]{2}{*}{0.47} \\
\hline \multirow{2}{*}{ A3 } & Alphabetic & 4 & 3.75 & 0.50 & \\
\hline & Orthographic & 15 & 4.00 & 0.38 & 0.27 \\
\hline \multirow{2}{*}{ B3 } & Alphabetic & 4 & 3.00 & 0.00 & \multirow{3}{*}{$0.04^{*}$} \\
\hline & Orthographic & 15 & 3.67 & 0.62 & \\
\hline \multirow{2}{*}{ A4 } & Alphabetic & 4 & 4.00 & 0.82 & \\
\hline & Orthographic & 15 & 5.00 & 0.85 & 0.05 \\
\hline \multirow{2}{*}{ B4 } & Alphabetic & 4 & 3.50 & 0.58 & \multirow[b]{2}{*}{0.59} \\
\hline & Orthographic & 15 & 3.73 & 0.88 & \\
\hline \multirow{2}{*}{ A5 } & Alphabetic & 4 & 15.00 & 0.00 & \\
\hline & Orthographic & 15 & 14.80 & 0.77 & 0.61 \\
\hline \multirow{2}{*}{ B5 } & Alphabetic & 4 & 14.00 & 0.82 & \multirow{3}{*}{$0.03^{*}$} \\
\hline & Orthographic & 15 & 14.80 & 0.41 & \\
\hline \multirow{2}{*}{ A6 } & Alphabetic & 4 & 1.75 & 0.50 & \\
\hline & Orthographic & 15 & 3.13 & 0.92 & $0.01^{*}$ \\
\hline
\end{tabular}

Note: $A=$ Average, $S D=$ Standard Deviation, Mann-Whitney, *significant.

\section{Discussion}

The aim of this study was to verify the performance of the working memory and reading level for proficient readers.

In this study, it became evident that as the age and education level increased, there was an improvement in the performance of the reading level and in working memory (Tables $\mathbf{1}$ and 3).

According to the literature, it is expected that the student from the 2nd to 4th year of elementary school, read texts whose content and form are familiar, and shows that he completely understood a text read by him or by someone through a conversation, a discussion, a recount or writing (Brasil, 2003).

The reading implies a decoding and understanding component. When learning to read, the reader can decode words in most texts, but does not meanthat an understanding of what is being read is occurring (Capovilla, 2005).

The present study showed that children in the 1st and 2nd year presented, in most cases, analphabetic reading level. The students of 3rd and 4th year were reading at the orthographic level, which allows for the automatic decoding of words, analysis of orthographic units, and the consequently of theses understanding (Figure 1 and Table 1).The performance of the working memory is associated with chronological age and learning. Thus, it is expected that older children have better performance on memory tasks than younger children, and this was attributed to maturity and schooling (Gindri, Keske-Soares, \& Mota, 2007).

As to the working memory, refers to the study by Barreyro, Burin and Duarte (2009) positive correlation between the performances of the child during the development of the reading tests in auditory working memory. The same authors also point out that the increase in storage capacity and processing of this memory facilitates the acquisition of new vocabulary and understanding of syntactically more complex sentences and of greater extent, containing redundant linguistic information. In addition, the auditory working memory helps the child to acquire metalinguistic skills such astasks of grammatical judgment of sentences.

These data corroborate this study concerning the performance improvement in the working memory to the impairment according to age. In the literature, failure in working memory is associated to disorders or oral and written language, and attention disorder, such as phonological disorder, specific language impairment, developmental dyslexia and ADHD (Ferreira, 2011; Barreyro, Burin, \& Duarte, 2009; Salgado, 2010; Nicolielo, Fernandes, Garcia, \& Hage, 2009).

Auditory and Visual working memory pointed in another study among proficient students in reading and writing, and students with a diagnosis of ADHD (Ferreira, 2011) included the analysis of the effects of phonological similarity, semantic extension, word in working memory, and verified the existence of differences performances according to the purpose for which the words were submitted. The author observed that words with phonological similarity are more difficult to be recalled due to

Table 3.

Correlation between age and the scores of the subtests of the protocol of working memory.

\begin{tabular}{cccccccccccccccc}
\hline & A1 & B1 & C1 & A2 & B2 & C2 & D2 & E2 & A3 & B3 & A4 & B4 & A5 & B5 & A6 \\
\hline R & 0.38 & 0.54 & 0.69 & 0.60 & 0.42 & 0.67 & 0.38 & 0.41 & 0.04 & 0.45 & 0.56 & 0.28 & 0.35 & 0.62 & 0.68 \\
p value & 0.11 & $0.02 *$ & $0.00^{*}$ & $0.01 *$ & 0.07 & $0.00^{*}$ & 0.11 & 0.08 & 0.87 & 0.05 & $0.01 *$ & 0.25 & 0.14 & $0.00^{*}$ & $0.00^{*}$
\end{tabular}

Note: $R$ = correlation coefficient of Spearman; *significant. 
generated the acoustic confusion. Another justification is that the representation of these words is subject to a partial loss caused by temporal deterioration, by interference from other phonological information or the difficulty to memorize the meaning of words (Fisher \& Craik, 1977). The results in Table 2 corroborate those found by Ferreira (2011). In that table it is observed that, on the evidence, and on C2 B3 involving recall of the word lists under the effect of phonological similarity, the average performance of the subjects were lower compared to the other subtests. Words with semantic similarity showed greater ease of recall, because the recall of words under this effect also involves the long-term memory. The span of memory increases when words that are repeated have semantic similarity, allowing to imagine a working memory made of multiple representations that constitute the same amount of buffer systems connected to each other (visual, auditory, lexical, phonological, semantic, motor, and etc.).

Table 2 shows that the average performance of recall of words with semantic similarity (B2) presented no statistically significant difference between the alphabetic reading and spelling phases. The lack of statistically significant performance might be due to the difference in $\mathrm{N}$ subjects in a phase and another reading. These results do not corroborate other findings (Ferreira, 2011; Cunha \& Capellini, 2010) because there was a statistically significant improvement in performance among proficient students recalling words under the effect of semantic similarity.

The results on the recall of polysyllabic words with complex phonology, and different semantics presented statistically significant difference between the subjects who were in alphabetic level and the orthographic level reading. Consider the positive effect of reading ability on working memory, mainly phonological, corroborating the study of Cunha, Capellini (2010) that investigated the performance of working memory in school from the 1st to 4th grade of elementary school. In the study, the authors observed an improvement of the average performance of remembrance of polysyllabic words throughout the school years.

The subjects' performance on the test recall of non-three syllable words (B5), displayed in Table 2, indicates a statistically significant difference between subject-level alphabet and spelling. The subjects who were at the orthographic level showed higher average performance than the subjects of alphabetic level. In the same table, it is observed that there was no statistically significant difference of the recall of non-syllable words.

These results allow us the discussion from the point of view that the memory of non-syllable words does not require too much use of phonological abilities, and therefore not sensitive to differentiate the performance of subjects in different age groups and levels of education. The repetition of non-three syllable words requires more efficient use of phonological awareness and the knowledge that this skill is intrinsically related to the level of education, promotes the development of finer levels of working memory, and it is able to justify the difference in performance in this study, which corroborates the findings of Ferreira (2011), Cunha and Capellini (2010).

The analysis of Table 2 of the subtests in Table 2 that presented differences statistically significant (with star *) shows that the development of working memory and reading has strengthened each other, because the subjects who had read at the orthographic level obtained better results in average performance work memory than the subjects with reading in al- phabetic level.

As to the visual aspect of working memory assessed by the material used in this study, the results presented in A4 and B4 subtests indicated the non-occurrence of a statistically significant difference between the group of children with reading in the alphabetic stage and the group of children with reading stage spelling (Table 2). I.e. the breakthrough performance of the reading level was not relevant to the occurrence of better performance in visual working memory. Although there is no performance difference between the visual subtests in relation to the reading level, the study showed that there is a positive correlation between age and visual recall in direct order (Table 3). These results are in line with the studyof Hitch, Wooding, Barker (1989), which states that the development of "visualspatial scheme" (sketchpad) in children 5 to 10 years old has little influence on the size of the stimulus and the similarity between them. However, Lopes, Lopes, Galera (2005) found improved performance on visual-spatial memory in children 11 to 12 years old. A study made by Barbosa, Bernardes, Misorelli, Chiappeta (2010). revealed that the acquisition of orthographic rules have positive relationship with the performance in visual working memory, revealing that the greater the number of misspelling committed in dictation, the worse the performance in visual working memory.

\section{Conclusion}

The present study shows that the performance of working memory and reading level is influenced by age and ranking of the subject. The results showed that participants in the 1st and 2nd year showed reading in the alphabetic stage and that the students of 3rd and 4th grade showed reading in the spelling stage. As to working memory, the results indicated that the participants of the 3rd and 4th year showed better performance in the assessment of working memory when compared with children from 1st and 2nd year. Regarding the variables that influenced the auditory working memory, in this study it was evident that the recall of words with phonological similarity was affected by auditory and temporal variables, but the recollection of words with semantic similarity features improved the performance over the earlier. Regarding the visual working memory, there were no significant differences between groups, but there was a positive correlation between age and visual recall in direct order. Therefore, it was observed that older children performed better on tasks of working memory than younger children, and this was attributed to the mutual, concomitant and bidirectional development between these skills.

\section{REFERENCES}

Barbosa, P. M. F., Bernardes, N. G. B., Misorelli, M. I., \& Chiappeta, A. L. M. L. (2010). Relação da memória visual com o desempenho ortográfico de crianças de $2^{\mathrm{a}}$ e $3^{\mathrm{a}}$ séries do ensino fundamental. $R e$ vista CEFAC, 12, 598-607.

http://dx.doi.org/10.1590/S1516-18462010000400009

Baddeley, A. (2000). The episodic buffer: A new component of the working memory? Trends in Cognitive Science, 4, 417-423. http://dx.doi.org/10.1016/S1364-6613(00)01538-2

Barreyro, J. P., Burin, D. I., \& Duarte, D. A. (2009). Capacidad de la memoria de trabajo verbal: Validez y fiabilidade de uma tarea de amplitud de lectura. Interdisciplinaria, 26, 207-228.

Brasil, Ministério da Educação. Parâmetros Curriculares Nacionais (2007). Brasília (DF): Ministério da Educação.

http://portal.mec.gov.br/seb/arquivos/pdf/vivro 02.pdf 


\section{T. L. FERREIRA ET AL.}

Capellini, S. A., \& Conrado, T. L. B. C. (2009). Desempenho de escolares com e sem dificuldades de aprendizagem de ensino particular em habilidade fonológica, nomeação rápida, leitura e escrita. $R e$ vista CEFAC, 11, 183-193.

Capellini, S. A., \& Cavalheiro, L.G. (2000). Avaliação do nível e da velocidade de leitura em escolares com e sem dificuldade na leitura. Temas sobre Desenvolvimento, 9, 5-12.

Capovilla, F.C. (2005). Os novos caminhos da alfabetização infantil: Relatório encomendado pela Câmara dos Deputados ao Painel Internacional de Especialistas em Alfabetização Infantil (2nd ed.) São Paulo: Memnon.

Carrilo-Mora, P. (2010). Sistemas de memória: Reseña histórica, clasificación y conceptos actuales. Salud Mental, 33, 197-205.

Cunha, V. L. O., \& Capellini, S. A. (2010). Análise psicolínguística e cognitive linguística das provas de habilidades metalinguisticas e leitura realizadas em escolares de $2^{\mathrm{a}}$ a $5^{\mathrm{a}}$ série. Revista CEFAC, 11 , 772-783. http://dx.doi.org/10.1590/S1516-18462010005000017

Gindri, G., Keske-Soares, M., \& Mota, H. B. (2007). Memória de trabalho, consciência fonológica e hipótese de escrita. Pró-Fono Revista de Atualização Científica, 19, 313-322.

Ferreira, T. L. (2011). A avaliação da memória de trabalho auditiva e visual em crianças com transtorno do déficit de atenção e hiperatividade. Campinas. Dissertação, Campinas (SP): Universidade Estadual de Campinas.

Fisher, R. P., \& Craik, F. I. M. (1977). Interaction between encoding and retrieval operations in cued recall. Journal of Experimental Psychology: Human Learning and Memory, 3, 701-711. http://dx.doi.org/10.1037/0278-7393.3.6.701

Frith, U. (1985). Beneath the surface of developmental dyslexia: In K. E. Patterson, J. C. Marshall, \& M. Colthear (Eds.), Surface dyslexia: Neuropsychological and cognitive analyses of phonological reading (pp. 301-330). London: Lawrence Erlbaum.

Hitch, G. J., Wooding, M. E., \& Barker, S. (1989). Visual and phono- logical components of working memory in young children. Memory \& Cognition, 16, 175-185. http://dx.doi.org/10.3758/BF03197067

Kibby, M. Y., Marks, W., Morgan, S., \& Long, C.J. (2004). Specific impairment in developmental reading disabilities: A working memory approach. Journal of Learning Disabilities, 37, 349-363. http://dx.doi.org/10.1177/00222194040370040601

Lopes, E. J., Lopes, R. F. F., \& Galera, C. A. (2005). Memória de trabalho viso-espacial em crianças de 7 a12 anos. Estudo de Psicologia, 10, 207-214. http://dx.doi.org/10.1590/S1413-294X2005000200007

Mourão Jr., C. A., \& Melo, L. B. R. (2011). Integração de três conceitos: Função executiva, memória de trabalho e aprendizado. Psicologia: Teoria e Pesquisa, 27, 309-314.

Nauhum, E. P. (1990). Meu caderno de redação (p. 131). São Paulo: Scipione.

Nicolielo, A. P., Fernandes, G. B., Garcia, V. L., \& Hage, S. R. V. (2008). Desempenho escolar de crianças com Distúrbio Específico de Linguagem: Relações com habilidades metafonológicas e memória de curto prazo. Revista da Sociedade Brasileira de Fonoaudiologia, 13, 246-250. http://dx.doi.org/10.1590/S1516-80342008000300008

Salgado, C. A. (2010). Programa de remediação fonológica, de leitura e escrita em crianças com dislexia de desenvolvimento. Campinas. [Tese]. Campinas (SP): Universidade Estadual de Campinas.

Stein, L. M. (1994). Teste de desempenho escolar: Manual para aplicação e interpretação. São Paulo: Casa do psicólogo.

Sternberg, R. J. (2000). Psicologia cognitiva. Porto Alegre: Artmed.

Tenório, S. M. P. C. P., \& Ávila, C. R. B. (2012) Processamento fonológico e desempenho escolar nas séries iniciais do ensino fundamental. Revista CEFAC, 14, 30-38. http://dx.doi.org/10.1590/S1516-18462011005000099

Van der Leij, A., \& Morfidi, E. (2006). Core deficits and variable differences in Dutch poor readers learning English. Journal of Learning Disabilities, 39, 74-90.

http://dx.doi.org/10.1177/00222194060390010701 